\title{
APPLICATION THE POINT FOUNDATION (PF) METHOD FOR SOFT SOIL IMPROVEMENT: A CASE STUDY FROM VETNAM
}

\author{
${ }^{1}$ Bui Truong Son*, ${ }^{1}$ Nguyen Thi Nu, ${ }^{1}$ Nguyen Thanh Duong and ${ }^{1}$ Nguyen Anh Ngoc \\ ${ }^{1}$ Department of Engineering Geology, Hanoi University of Mining and Geology, Hanoi, Vietnam \\ *Email: buitruongson@humg.edu.vn \\ Received: 11 August 2020; accepted: 9 September 2020
}

\begin{abstract}
The point foundation method is the head enlarged cement deep mixing columns with highquality control which can be used for soft ground improvement. The article aims to present the application of this method to treat soft soil for the foundation of Samse Vina factory, Ninh Binh province. The thickness of soft soil varies from $5.4 \mathrm{~m}$ to $7.4 \mathrm{~m}$ with high compressibility and low shear strength. Thus, point foundation was used to improve this layer. The prediction methods of soil bearing capacity and the settlement on the point foundation were calculated. After the treatment of soil, the unconfined compression strength of the point foundation column was determined and the static compression test for the point foundation column was also performed. The research results show that this method can significantly reduce the settlement of shallow footing and improved the bearing capacity of the soil. The final settlement of shallow footing was smaller than $2.54 \mathrm{~cm}$ and the bearing capacity of soil treatment can be satisfied with the requirement of construction building. This is a successful case of the application of point foundation to improve soft soil in Vietnam.
\end{abstract}

Keywords: Point foundation; Soft soil; Capacity; Settlement

\section{INTRODUCTION}

Vietnam has two large deltas, including Red river and Mekong deltas. Due to the deposition of young sediments, soft soil is widely distributed in these deltas. The thickness of soft soil layers varies from a few meters to more than 30-50 meters (Bui Truong et al., 2020; Giao and Hien, 2007; Nu et al., 2020; Nguyen Thi et al., 2020 and Nu and Thinh, 2020). Recently, the demand for the development of infrastructure in these areas is on the rise, so the soft ground needs to be improved before construction. In Vietnam, many methods have been used for the treatment of soft soil such as sand column, sand well, prefabricated vertical drain (PVD), and cement deep mixing (CDM). Moreover, in Vietnam, soft soil can be improved by mixing with cement and coal bottom ash from thermal power plants (Nu et al., 2019 and Nguyen Thi et al., 2019). 
However, the soft soils often have different origins, many compositions, and distribute at different depths. It is not easy to find suitable methods for soft soil improvement. Additionally, each soft soil treatment method has its advantages and disadvantages. Therefore, it is necessary to find out other methods for soft soil improvement.

Among the variety of soft soil improvement methods, CDM method has been widely used in the world for a long time, especially in the US, Japan. CDM is the method that uses the original Portland cement or a mixture of Portland cement and blast - furnace slag to mix with the soft soil. CDM is an economical and effective method to reduce the compressibility and permeability of the soil, increase the soil bearing capacity, and the resistance against liquefaction (Asturias and Lorenzo, 2015). The diameters of the CDM column vary from 0.6 to $1.5 \mathrm{~m}$ and can expend to $40 \mathrm{~m}$ in depth. The main purposes of CDM method are to significantly increase the strength and stiffness, decrease the permeability and compressibility of the native soil (Bruce, 2000; Chen et al., 2013 and Dehghanbanadaki et al., 2013). However, the conventional CDM method often creates the soil-cement column with a constant diameter. This can lead to low effectiveness of this method in increasing the bearing capacity of the soft ground. Additionally, the CDM method is also inefficient in the case of shallow footings if the upper soft soil layer is subject to a larger amount of induced stress from loading (Nguyen et al., 2020).

To reduce the disadvantage of CDM, the improvement of the CDM method has been developed. One of the improvements is the head - enlarged CDM column which is called a point foundation (PF) (Fig. 1). A head - enlarged CDM column is an improved CDM method that has a larger head and small tail (A. N. Nguyen et al., 2020). The method has been used in Korea for ground improvement of more than 150 projects and has been presented in the United States. A. N. Nguyen et al. (2020) indicated that the settlement of a footing on PF columns can reduce up to $10 \%$ as compared with that from the same footing on CDM columns. T. D. Nguyen et al. (2020) evaluated the stiffness enhancement of ground improvement by analytical and numerical analyses and indicated that the PF method produced a more proper stiffness distribution with depth. Moreover, this method can significantly reduce the settlement of shallow footing, the cost, and the time of construction as compared to the conventional CDM method. In Vietnam, the PF method is rarely used and there are no quantitative reports on its application for soft ground improvement. Therefore, this paper will present the case study of the application of PF method to improve soft soil for the foundation construction in Samse Vina factory, Ninh Binh province of Vietnam. Thi Nu et al. 2020 mentioned that the increase in salt and alum contents caused a decrease in undrained shear strength and an increase in liquid limit 
and compression index. Thus, the salt content in soil can impact many fields (Al-Hamdani et al., 2016). Many investigations have been conducted to examine the suitability of soil stabilization with RHA and cement. The soft soils are widely distributed in this area with the thickness from a few meters to more than thirty meters. The distribution of soil layers in this area has common characteristics of soil ground in the Red river delta. The main purposes of this paper are to clarify the method for calculating soil bearing capacity and settlement of shallow foundation on soft soil improvement by PF method; evaluate the quality of treated soil after the construction of PF column. The result of this study will provide knowledge and information for the application of PF method in engineering practice as well as a reference for further research.

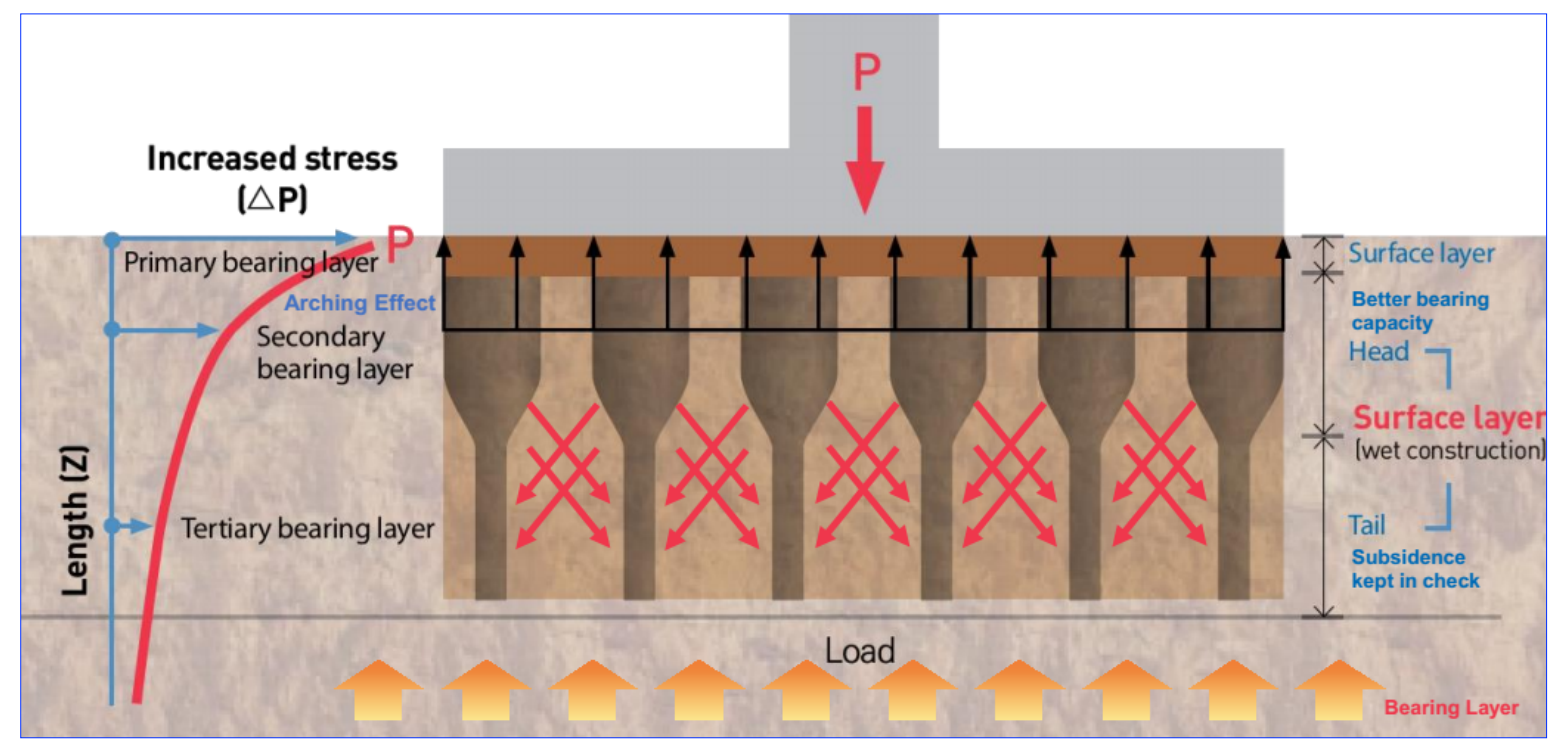

Fig. 1. The description of PF method in soft ground (EXT, 2020). MATERIALS AND METHODS

\section{Properties of Samse Vina Factory}

The Samse Vina factory is located in Cau Yen industrial zone, Ninh Binh province of Vietnam (Fig. 2). The total area of the factory is $8773.65 \mathrm{~m}^{2}(97 \mathrm{~m} \times 90.45 \mathrm{~m})$. The factory is built from steel frame structure and the total of the load acting on the ground is $120000 \mathrm{KN}$ (Table 1).

\section{Ground Profile and Properties of Soil}

In the Samse Vina factory, five boreholes were conducted to investigate the ground profile. The soil samples were collected from these boreholes. After that, the soil samples were prepared to determine the physico-mechanical properties of soil layers. Particle size analysis and Atterberg limits of soil were determined according to the American Society for Testing and Materials (ASTM) standard ASTM D422-63 (2007) and ASTM D4318-17 (2017) in respective. 


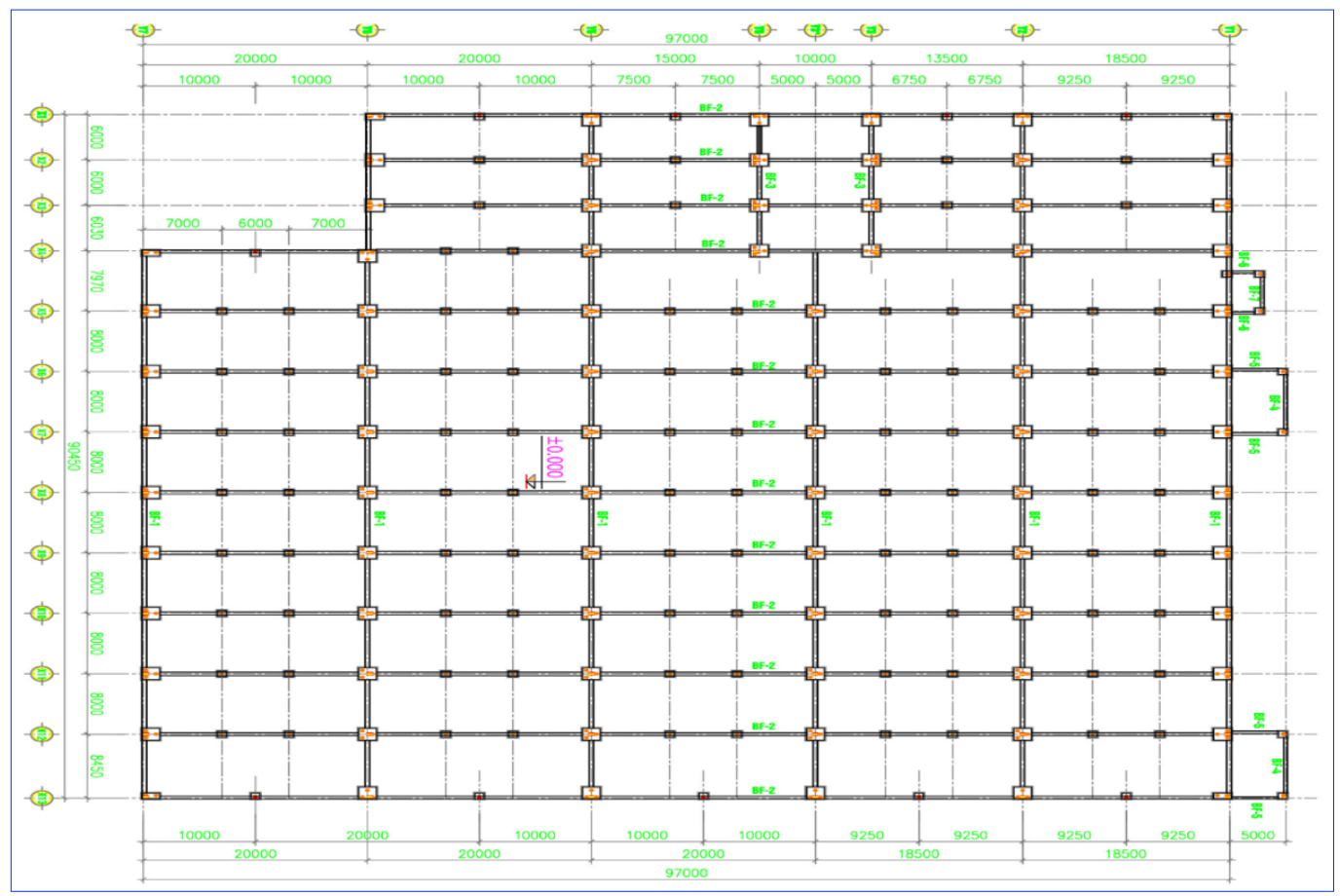

Fig. 2. Samse Vina factory site

Table 1. The quantity of foundation and the demand dead load on the foundation

\begin{tabular}{|c|c|c|c|c|}
\hline No & Name of foundation & Quantity of foundation & $\begin{array}{l}\text { Demand load on the } \\
\text { foundation, } \mathrm{P}, \mathrm{kN}\end{array}$ & $\begin{array}{l}\text { The total } \\
\text { load, } \mathrm{kN}\end{array}$ \\
\hline 1 & PF1 & 26 & 1200 & 31200 \\
\hline 2 & PF2 & 5 & 800 & 4000 \\
\hline 3 & PF3 & 6 & 1200 & 7200 \\
\hline 4 & PF4 & 2 & 1200 & 2400 \\
\hline 5 & PF5-1 & 4 & 1400 & 5600 \\
\hline 6 & PF5 & 26 & 1200 & 31200 \\
\hline 7 & PF6 & 2 & 1400 & 2800 \\
\hline 8 & PF7 & 1 & 1400 & 1400 \\
\hline 9 & PF8 & 1 & 1400 & 1400 \\
\hline 10 & PF9 & 2 & 1400 & 2800 \\
\hline 11 & PF10 & 2 & 1400 & 2800 \\
\hline 12 & PF11 & 1 & 1200 & 1200 \\
\hline 13 & PF12 & 1 & 1200 & 1200 \\
\hline 14 & PF13 & 13 & 400 & 5200 \\
\hline 15 & PF14 & 1 & 400 & 400 \\
\hline 16 & PF15 & 48 & 400 & 19200 \\
\hline \multicolumn{2}{|c|}{ Total } & 141 & & $\begin{array}{c}120 \\
000\end{array}$ \\
\hline
\end{tabular}

The oedometer tests were performed according to ASTM D2485-18 (2018) standard to determine the properties of consolidation. The unconsolidated undrained (UU) shear box test was used to determine the undrained shear strength of soil in accordance with ASTM D3080- 
04 (2004). The geotechnical soil properties are shown in Table 2. The ground profile of the study area is plotted in Fig. 3. The ground profile consists of five soil layers, including:

Layer 1: Filling soil with a thickness of $1.2 \mathrm{~m}$ to $1.5 \mathrm{~m}$ with a mean value of $1.4 \mathrm{~m}$.

Layer 2: Soft sandy clay soil contains some organic matters. The thickness varies from $5.4 \mathrm{~m}$ to $7.4 \mathrm{~m}$ with an average value of $6.6 \mathrm{~m}$.

Layer 3: Firm sandy clay. The thickness changes from $4.5 \mathrm{~m}$ to $6.0 \mathrm{~m}$ with a mean value of $5.2 \mathrm{~m}$. Layer 4: Stiff sandy clay soil. Thickness varies from $7.9 \mathrm{~m}$ to $9.8 \mathrm{~m}$ with an average of $8.8 \mathrm{~m}$. Layer 5: Very stiff sandy clay with a thickness of $10 \mathrm{~m}$.
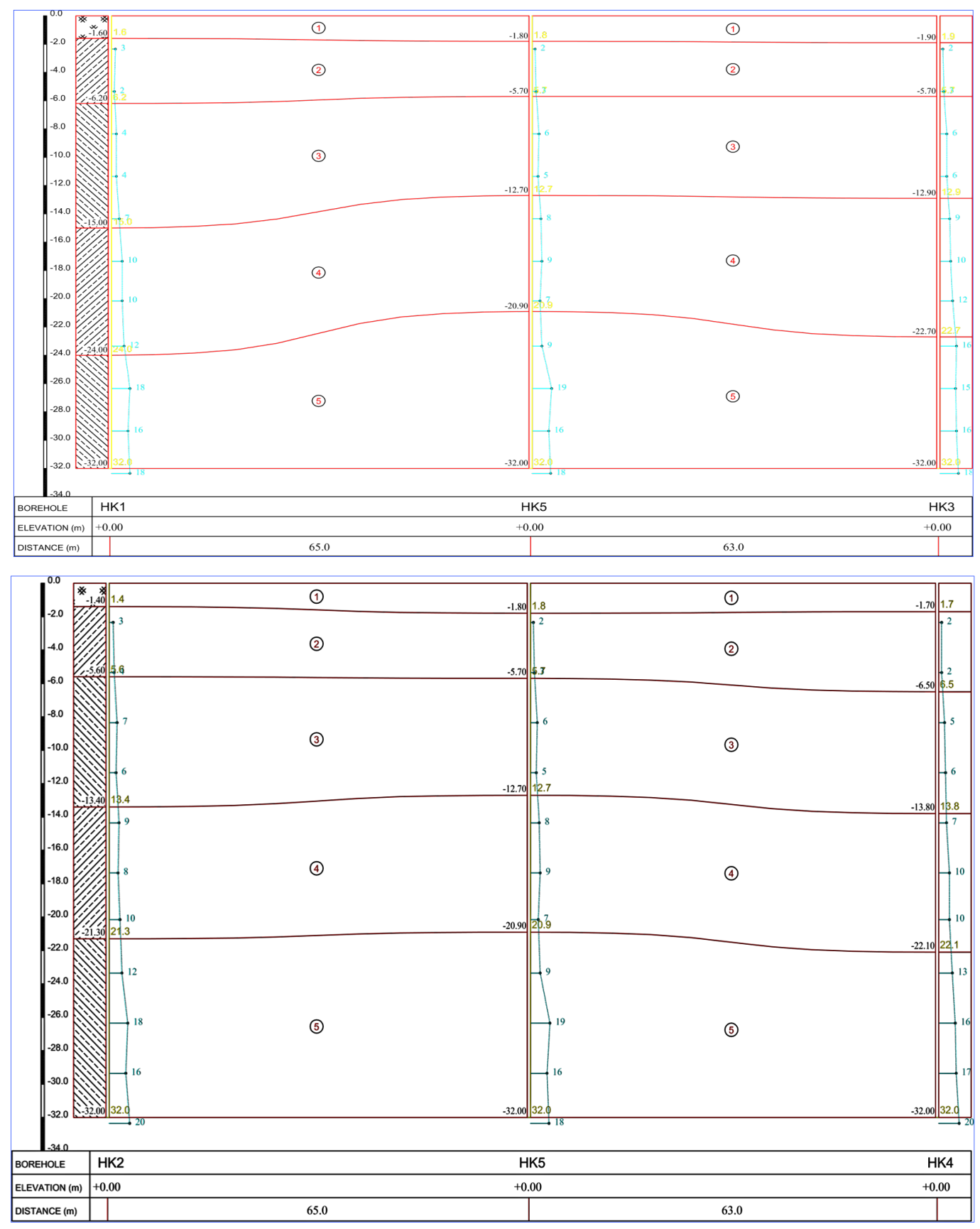

Fig. 3. Engineering geological section 
Table 2. The physico-mechanical properties of soil layers

\begin{tabular}{|c|l|c|c|c|c|}
\hline No. & \multicolumn{1}{|c|}{ Properties } & Layer 2 & Layer 3 & Layer 4 & Layer 5 \\
\hline 1 & Natural water content, $\mathrm{w}, \%$ & 40.9 & 34.1 & 29.6 & 22.5 \\
\hline 2 & Bulk unit weight, $\gamma_{\mathrm{w}}, \mathrm{kN} / \mathrm{m}^{3}$ & 17.5 & 17.9 & 18.2 & 18.7 \\
\hline 3 & Dry unit weight, $\gamma_{\mathrm{c}}, \mathrm{kN} / \mathrm{m}^{3}$ & 12.4 & 13.4 & 14.0 & 15.3 \\
\hline 4 & Specific gravity, $\rho$ & 26.8 & 26.9 & 27.0 & 27.1 \\
\hline 5 & Saturation degree, $\mathrm{G}, \%$ & 94.7 & 90.4 & 86.6 & 78.1 \\
\hline 6 & Void ratio, e & 1.158 & 1.009 & 0.923 & 0.775 \\
\hline 7 & Liquid limit, $\mathrm{LL}, \%$ & 43.8 & 39.1 & 39.7 & 34.5 \\
\hline 8 & Plastic limit, $\mathrm{PL}, \%$ & 28.9 & 24.6 & 24.7 & 19.5 \\
\hline 9 & Plasticity index, $\mathrm{I}$ & 14.9 & 14.5 & 15.0 & 15.0 \\
\hline 10 & Liquidity index, $\mathrm{I}_{\mathrm{S}}$ & 0.81 & 0.66 & 0.33 & 0.20 \\
\hline 11 & Cohesion force, $\mathrm{C}, \mathrm{kN} / \mathrm{m}^{2}$ & 11.8 & 16.2 & 22.6 & 271 \\
\hline 12 & Friction angle, $\varphi$, degree & $4^{\circ} 14$ & $8^{\circ} 25^{\prime}$ & $11^{\circ} 57^{\prime}$ & $15^{\circ} 56$ \\
\hline 13 & Coefficient of compression, $\mathrm{a}_{1-2}, \mathrm{kPa}^{-1}$ & 7.8 & 4.2 & 2.9 & 2.1 \\
\hline 14 & Compression index, $\mathrm{Cc}$ & 0.364 & 0.156 & 0.105 & 0.082 \\
\hline 15 & Recompression index, $\mathrm{Cr}$ & 0.062 & 0.025 & 0.010 & 0.009 \\
\hline 16 & Preconsolidation pressure, $\mathrm{Pc}, \mathrm{kPa}^{-1}$ & 56 & 90 & 123 & 179 \\
\hline 17 & Coefficient of consolidation, $10^{-3} \mathrm{~cm}^{2} / \mathrm{s}$ & 0.32 & 0.56 & 1.23 & 1.59 \\
\hline 14 & Deformation modulus, $\mathrm{E}_{0}, \mathrm{kN} / \mathrm{m}^{2}$ & 1700 & 6500 & 1080 & 1960 \\
\hline 15 & Conventional capacity, $\mathrm{R}_{\mathrm{o}}, \mathrm{kN} / \mathrm{m}^{2}$ & 65 & 95 & 139 & 187 \\
\hline
\end{tabular}

As also shown in Table 2, the layer 2 has the lowest bearing capacity and highest compressibility. The layers 4 and 5 have the higher bearing capacity and lower compressibility than those of layers 2 and 3. Thus, soil layer 2 is soft soil and cannot meet the construction load, so it must be improved to increase the soil strength, bearing capacity, and reduce the compressibility.

\section{Design and Quality of Soil Treated by the PF Method}

\section{Determining the parameters of foundation and PF column}

There are four types of foundation with the load acting on the bottom of the foundation is 400 KN (F-400KN), 800KN (F-800KN), 1200KN (F-1200KN), 1400KN (F-1400 KN) respectively and the requirement of soil strength after treatment by $P F$ method $\left(Q_{a}\right)$ equals $250 \mathrm{KN} / \mathrm{m}^{2}$. The area of the foundation (A) must be satisfied with the following equation:

$$
A \geq \frac{P}{Q_{a}}
$$

In the case of square footing:

$$
\begin{aligned}
A & =\frac{P}{Q_{a}} \\
A & =B \cdot L \\
B & =L
\end{aligned}
$$


where: $\mathrm{B}$ is the width of foundation, $\mathrm{m}$; $\mathrm{L}$ is the length of foundation, $\mathrm{m} ; \mathrm{P}$ is demand load on the foundation, $\mathrm{kN}$.

The length, width, and area of the foundation were calculated from equation 2 (Table 3). The diameters of the head, cone, and tail of the PF column are chosen equal to $1.2 \mathrm{~m}, 1.0 \mathrm{~m}$, and $0.8 \mathrm{~m}$ respectively (EXT, 2017). The DB 6000 material with high compressive strength of 140 $\mathrm{kN} / \mathrm{m}^{2}$ was used for PF column. The amount of DB 6000 used is $250 \mathrm{~kg} / \mathrm{m}^{3}$ and $150 \mathrm{~kg} / \mathrm{m}^{3}$ for PF-M and PF-S types in respective. The unconfined compressive strength $\left(\mathrm{q}_{\mathrm{u}}\right)$ and the elastic modulus of PF column are $2000 \mathrm{kPa}$ and $300000 \mathrm{kPa}$ respectively. Some other properties of PF column include unit weight $\left(19 \mathrm{kN} / \mathrm{m}^{3}\right)$, cohesion force $\left(30 \mathrm{kN} / \mathrm{m}^{3}\right)$, and friction angle $\left(33^{0}\right)$ The ratio of replacement of PF column is calculated as follows (EXT, 2017):

$$
a=\frac{n A_{c}}{B L}
$$

The ratio of replacement of the PF column must be more than 0.6 (EXT, 2020). So, the number of PF columns was chosen to meet this requirement. After that, the ratio of replacement of the PF column was calculated from equation 5 (Table 3 ). There are sixteen square shallow foundations (PF1-PF15-1) with a total of 141 foundations. The total area foundation is $517.76 \mathrm{~m}^{2}$. The width and length of the square foundation were $1.3 \mathrm{~m}$ to $2.5 \mathrm{~m}$. The properties of these foundations are presented in Fig. 4. These foundations were improved by a total of 368 PF columns and the number of PF columns in each shallow changed from 2 to 78 PF columns.

Table 3. The parameters of foundation and PF column

\begin{tabular}{|c|c|c|c|c|c|c|c|c|c|c|}
\hline $\begin{array}{c}\text { Name of } \\
\text { foundation }\end{array}$ & $\begin{array}{c}\text { Quantity of } \\
\text { foundation }\end{array}$ & $\begin{array}{c}\mathbf{B}, \\
\mathbf{m}\end{array}$ & $\begin{array}{c}\mathbf{L}, \\
\mathbf{m}\end{array}$ & $\begin{array}{c}\mathbf{A}, \\
\mathbf{m}^{2}\end{array}$ & $\sum \boldsymbol{A}, \mathbf{m}^{2}$ & $\begin{array}{c}\mathbf{a}, \\
\mathbf{\%}\end{array}$ & $\begin{array}{c}\text { Number of PF } \\
\text { per foundation }\end{array}$ & $\begin{array}{c}\text { Total } \\
\mathbf{P F}\end{array}$ & $\begin{array}{c}\text { Actual } \\
\mathbf{l o a d}, \mathbf{k N}\end{array}$ & $\begin{array}{c}\mathbf{P}, \\
\mathbf{k N}\end{array}$ \\
\hline PF1 & 26 & 2.20 & 2.20 & 4.84 & 125.84 & 70 & 3 & 78 & 1210 & 1200 \\
\hline PF2 & 5 & 1.80 & 1.80 & 3.24 & 16.20 & 70 & 2 & 10 & 810 & 800 \\
\hline PF3 & 6 & 2.20 & 2.20 & 4.84 & 29.04 & 70 & 3 & 18 & 1210 & 1200 \\
\hline PF4 & 2 & 2.20 & 2.20 & 4.84 & 9.68 & 70 & 3 & 6 & 1210 & 1000 \\
\hline PF5-1 & 4 & 2.50 & 2.50 & 6.25 & 25.00 & 72 & 4 & 16 & 1563 & 1400 \\
\hline PF5 & 26 & 2.20 & 2.20 & 4.84 & 125.84 & 70 & 3 & 78 & 1210 & 1200 \\
\hline PF6 & 2 & 2.50 & 2.50 & 6.25 & 12.50 & 72 & 4 & 8 & 1563 & 1400 \\
\hline PF7 & 1 & 2.50 & 2.50 & 6.25 & 6.25 & 72 & 4 & 4 & 1563 & 1400 \\
\hline PF8 & 1 & 2.50 & 2.50 & 6.25 & 6.25 & 72 & 4 & 4 & 1563 & 1400 \\
\hline PF9 & 2 & 2.50 & 2.50 & 6.25 & 12.50 & 72 & 4 & 8 & 1563 & 1400 \\
\hline PF10 & 2 & 2.50 & 2.50 & 6.25 & 12.50 & 72 & 4 & 8 & 1563 & 1400 \\
\hline PF11 & 1 & 2.20 & 2.20 & 4.84 & 4.84 & 70 & 3 & 3 & 1210 & 1200 \\
\hline PF12 & 1 & 2.20 & 2.20 & 4.84 & 4.84 & 70 & 3 & 3 & 1210 & 1200 \\
\hline PF13 & 13 & 1.80 & 1.80 & 3.24 & 42.12 & 70 & 2 & 26 & 810 & 400 \\
\hline PF14 & 1 & 1.80 & 1.80 & 3.24 & 3.24 & 70 & 2 & 2 & 810 & 400 \\
\hline PF15-1 & 48 & 1.30 & 1.30 & 1.69 & 81.12 & 67 & 1 & 48 & 423 & 400 \\
\hline Total & 141 & & & & 517.76 & & & 368 & & \\
\hline
\end{tabular}




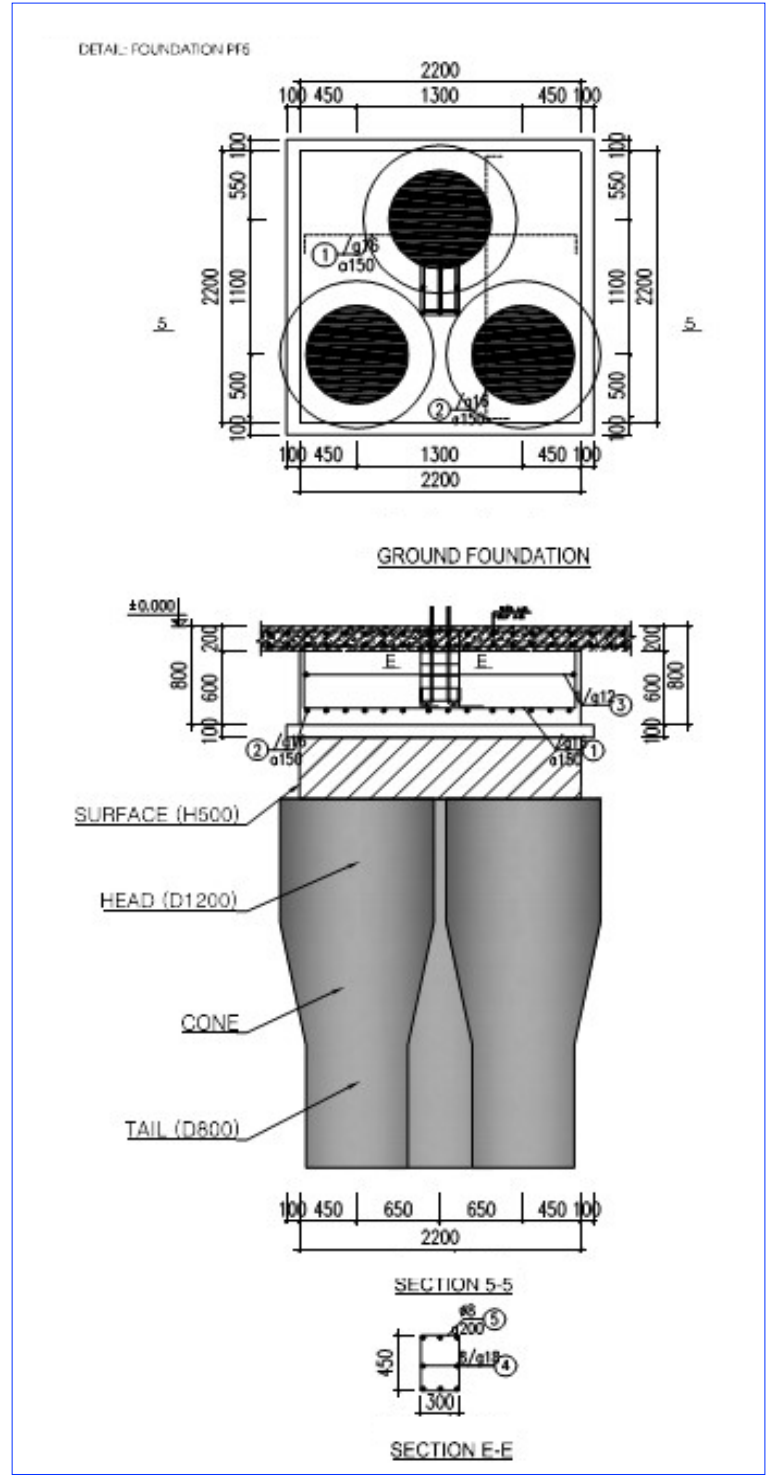

Fig. 4. A shallow foundation of F-1400 (PF8) with soft improvement using PF

\section{Estimation of the soil bearing capacity}

After treated soft soil by PF method, the ultimate bearing capacity for square foundations was calculated by Terzaghi's theory, Meyerhof 's theory, and Hansen's theory. Terzaghi bearing capacity equation was propesed by Terzaghi (Bowles, 1996) as follows:

$$
q_{u l t}=c N_{c} s_{c}+\overline{\bar{q}} N_{q}+0.5 \gamma B N_{\gamma} s_{\gamma}
$$

Where:

$$
N_{q}=\frac{a^{2}}{a \cos ^{2}\left(45+\frac{\varphi}{2}\right)} \quad ; a=e^{\left(0.75 \pi-\frac{\varphi}{2}\right) \tan \varphi} ; N_{c}=\left(N_{q}-1\right) \cos \varphi ; N_{\gamma}=\frac{\tan \varphi}{2}\left(\frac{K_{p \gamma}}{\cos ^{2} \varphi}-1\right)
$$

$\mathrm{c}$ is apparent cohesion intercept; $\overline{\bar{q}}=\gamma . \mathrm{D} ; \gamma$ is unit weight; $\mathrm{D}$ is the depth of foundation; $\mathrm{B}$ is the width of foundation; $\varphi$ is friction angle; $s_{c}, s_{\gamma}$ are the shape factors; for square shallow: $s_{c}=1.3$ and, $\mathrm{s}_{\gamma}=0.8$. 
Meyerhof bearing capacity equation was proposed by Meyerhof (Bowles,1996) as shown following:

$$
q_{u l t}=c N_{c} s_{c} d_{c}+\overline{\bar{q}} N_{q} s_{q} d_{q}+0.5 \gamma B^{\prime} N_{\gamma} s_{\gamma} d_{\gamma}
$$

Where:

$$
N_{q}=e^{\pi \tan \varphi} \tan ^{2}\left(45+\frac{\varphi}{2}\right) \quad ; \quad N_{c}=\left(N_{q}-1\right) \cos \varphi \quad ; \quad N_{\gamma}=\left(N_{q}-1\right) \tan (1.4 \varphi)
$$

$d_{c}, d_{q}$ and $d_{\gamma}$ are depth factors respectively.

Hansen bearing capacity equation was proposed by Bowles, 1996 as follows:

$$
q_{u l t}=c N_{c} s_{c} d_{c} i_{c} g_{c} b_{c}+\overline{\bar{q}} N_{q} d_{q} i_{q} g_{q} b_{q}+0.5 \gamma B^{\prime} N_{\gamma} s_{\gamma} d_{\gamma} i_{\gamma} g_{\gamma} b_{\gamma}
$$

Where:

$$
N_{q}=e^{\pi \tan \varphi} \tan ^{2}\left(45+\frac{\varphi}{2}\right) \quad ; \quad N_{c}=\left(N_{q}-1\right) \cos \varphi \quad ; \quad N_{\gamma}=1.5\left(N_{q}-1\right) \tan (\varphi)
$$

$\mathrm{i}_{\mathrm{c}}, \mathrm{i}_{\mathrm{q}}$ and $\mathrm{i}_{\gamma}$ are load inclination factors; $\mathrm{g}_{\mathrm{c}}, \mathrm{g}_{\mathrm{q}}$ and $\mathrm{g}_{\gamma}$ are ground inclination factors; $\mathrm{b}_{\mathrm{c}}, \mathrm{b}_{\mathrm{q}}$ and $\mathrm{b}_{\gamma}$ are base inclination factors.

\section{Estimation of the settlement of shallow footing}

The settlement of the ground treatment by P.F method under footing was calculated as follows (Vietnamese Standard-TCVN 9403-2012, 2012):

$$
\mathrm{S}=\mathrm{S}_{1}+\mathrm{S}_{2}
$$

Where: $S_{1}$ is the settlement of soil - PF mixture.

$\mathrm{S}_{2}$ is the settlement of natural soil under footings.

$\mathrm{S}_{1}$ was calculated as follows:

$$
S_{1}=\frac{q \cdot H}{E_{t b}}=\frac{q \cdot H}{a \cdot E_{c}+(1-a) \cdot E_{S}}
$$

$\mathrm{E}_{\mathrm{tb}}$ is deformation modulus of soil improvement by PF.

$$
E_{t b}=a E_{c}+(1-a) E_{s}
$$

$\mathrm{E}_{\mathrm{c}}$ is deformation modulus of PF; $\mathrm{E}_{\mathrm{s}}$ is deformation modulus of soft soil; $\mathrm{q}$ is actual load under the shallow footing, $\mathrm{kN} / \mathrm{m}^{2}$.

$$
\mathrm{q}=\mathrm{Q}_{\mathrm{a}}+\mathrm{h}_{\mathrm{pf}-\mathrm{s} \cdot} \cdot \gamma_{\mathrm{dn} 1}-\mathrm{D}_{\mathrm{f} \cdot} \cdot \gamma_{2}
$$


$\mathrm{h}_{\text {pf-s }}$ is the height of the buffer layer of PF-S pile head (buffer layer), $\mathrm{h}_{\mathrm{pf}-\mathrm{s}}=0.5 \mathrm{~m} ; \gamma_{\mathrm{dn} 1}$ is the unit weight of PF-S, $\gamma_{\mathrm{dn} 1}=19 \mathrm{kN} / \mathrm{m}^{3} ; \mathrm{D}_{\mathrm{f}}$ is the depth of shallow footing, $\mathrm{D}_{\mathrm{f}}=1.3 \mathrm{~m} ; \gamma_{\mathrm{dn} 2}$ is the unit weight of the filling layer, $\gamma_{\mathrm{dn} 2}=18 \mathrm{kN} / \mathrm{m}^{3}$.

$$
\mathrm{q}=250+0.5 \times 19-1.3 \times 18=236.1 \mathrm{kN} / \mathrm{m}^{2}
$$

In order to compare with the total settlement of shallow footings before improvement $\left(\mathrm{S}_{0}\right), \mathrm{S}_{0}$ was calculated as follows (Vietnamese standard TCVN 9362: 2012):

$$
S_{0}=\sum_{i=1}^{j} \sigma_{p t} \cdot h_{i} \cdot \frac{\beta}{E_{s i}}
$$

where $\beta$ is coefficient; $\beta=0.8 ; h_{i}$ is the thickness of layer $i$; $E_{s i}$ is deformation modulus of layer $\mathrm{i} ; \sigma_{p t}$ is additional stress at the middle of layer; $\sigma_{p t}=K_{0} . q ; \mathrm{K}_{0}$ is the coefficient depending on the $1 / \mathrm{b}$ and $\mathrm{z} / \mathrm{b}$ (Poulos and Davis, 1974).

$\mathrm{S}_{2}$ - the settlement of natural soil under PF column was calculated as follows (An, 2012):

$$
S_{2}=\frac{C_{c}}{1+e_{0}} h_{2} \log _{10} \frac{\sigma_{v 0 \prime}+q_{2}}{\sigma_{v 0 \prime}}
$$

where: $\mathrm{h}_{2}$ is the depth of firm soil (layer 3) under PF column, $\mathrm{m} ; \mathrm{h}_{2}=1.9 \mathrm{~m} ; \mathrm{C}_{\mathrm{c}}$ is compression index of layer 3 ; $\mathrm{e}_{\mathrm{o}}$ is the void ratio of layer $3 ; \sigma^{\prime}$ vo is effective stress of soil layer; $\mathrm{q}_{2}$ - actual load under the PF column (An, 2012), $\mathrm{kN} / \mathrm{m}^{2}$.

$$
\mathrm{q}_{2}=\frac{q B}{B+\frac{\mathrm{h} 2}{2}}=171 \mathrm{kPa}
$$

\section{Assessment of the quality of soil treated by the PF method}

Firstly, the construction of the PF method can be described as follows in Fig. 5. Secondly, after 3 days, the PF column was stiff and the buffer layer was constructed as shown in Fig. 6.

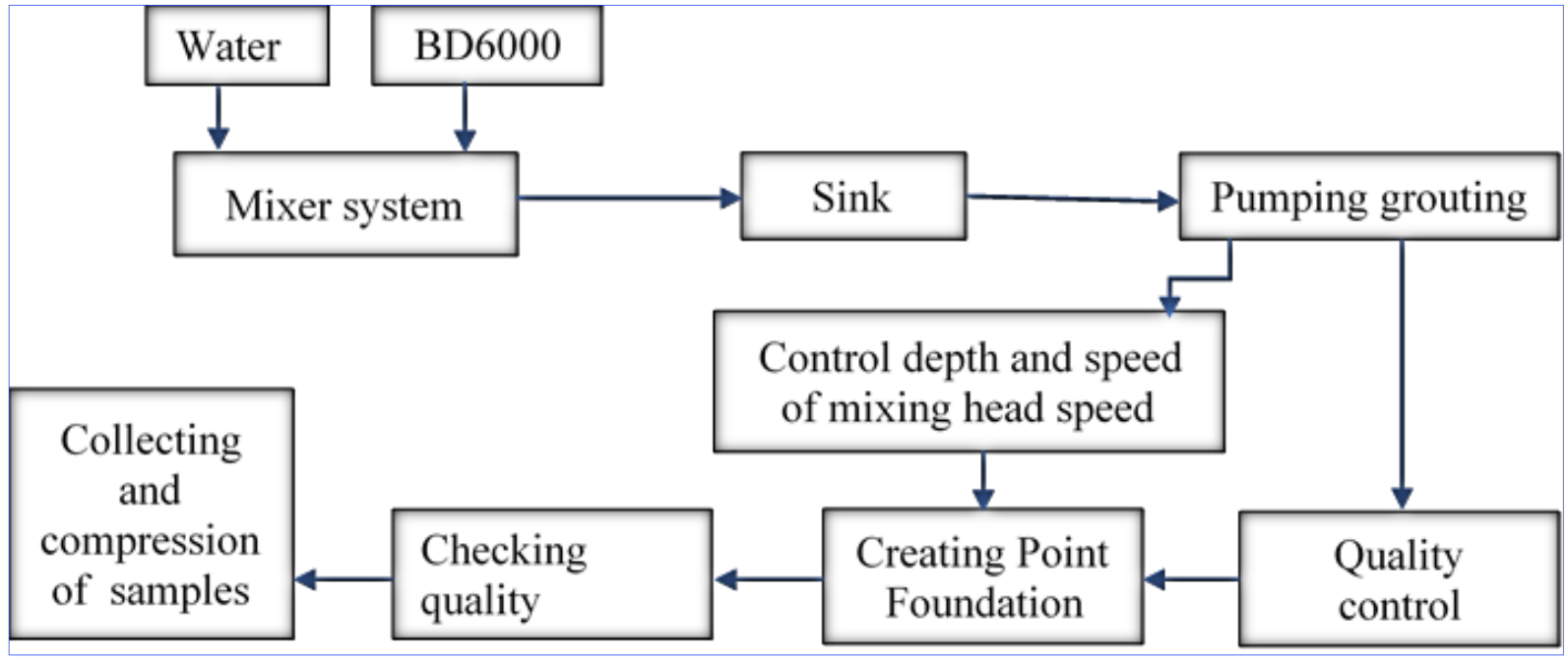

Fig. 5. The construction of PF method 
The time for construction is very quick and it does not need to make pile caps, so it reduces the labor and material cost. In the construction stage, the machine is very flexible because of using the excavator base machine and can be used for a narrow construction area.

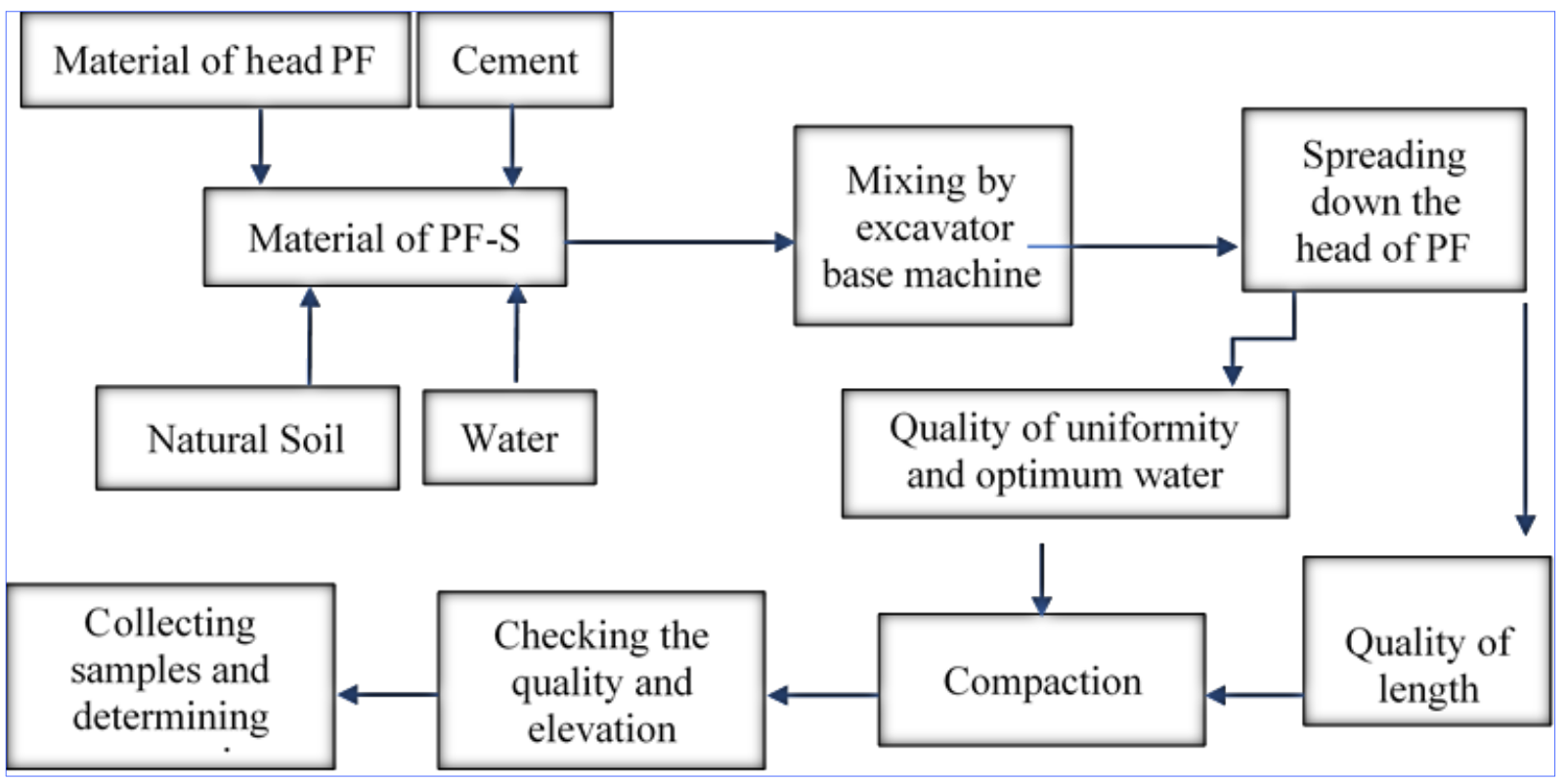

Fig. 6. The construction of PF-S (the buffer layer of PF column)

The construction procedures are described in detail in Nguyen et al. (2020). Firstly, the excavator base machine (Fig.7 and Fig. 8) was moved on to the center of the right location and the center of PF column, and the vertical agitation rod was checked. The mixing of water and DB6000 was prepared for pumping into the soft ground. Secondly, soft soil was stirred and the binder was pumped to the design depth with the speed of $2.0 \mathrm{~m} /$ minute. Thirdly, at the depth design, the agitation rod was moved up and down with 2-3 times to mix homogeneously soft soil with water and DB6000. Finally, soft soil with water and DB6000 was stirred and the agitation rod was retracted until the PF column was completed.
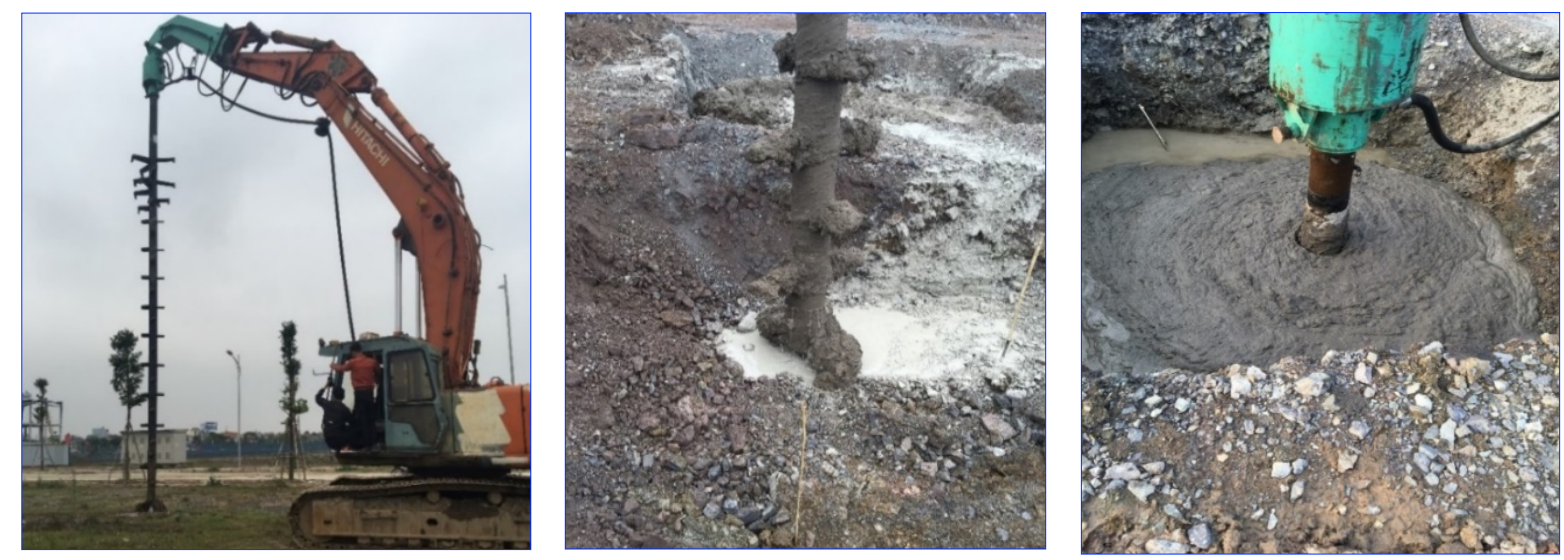

Fig.7. The excavator base machine for creating PF column 

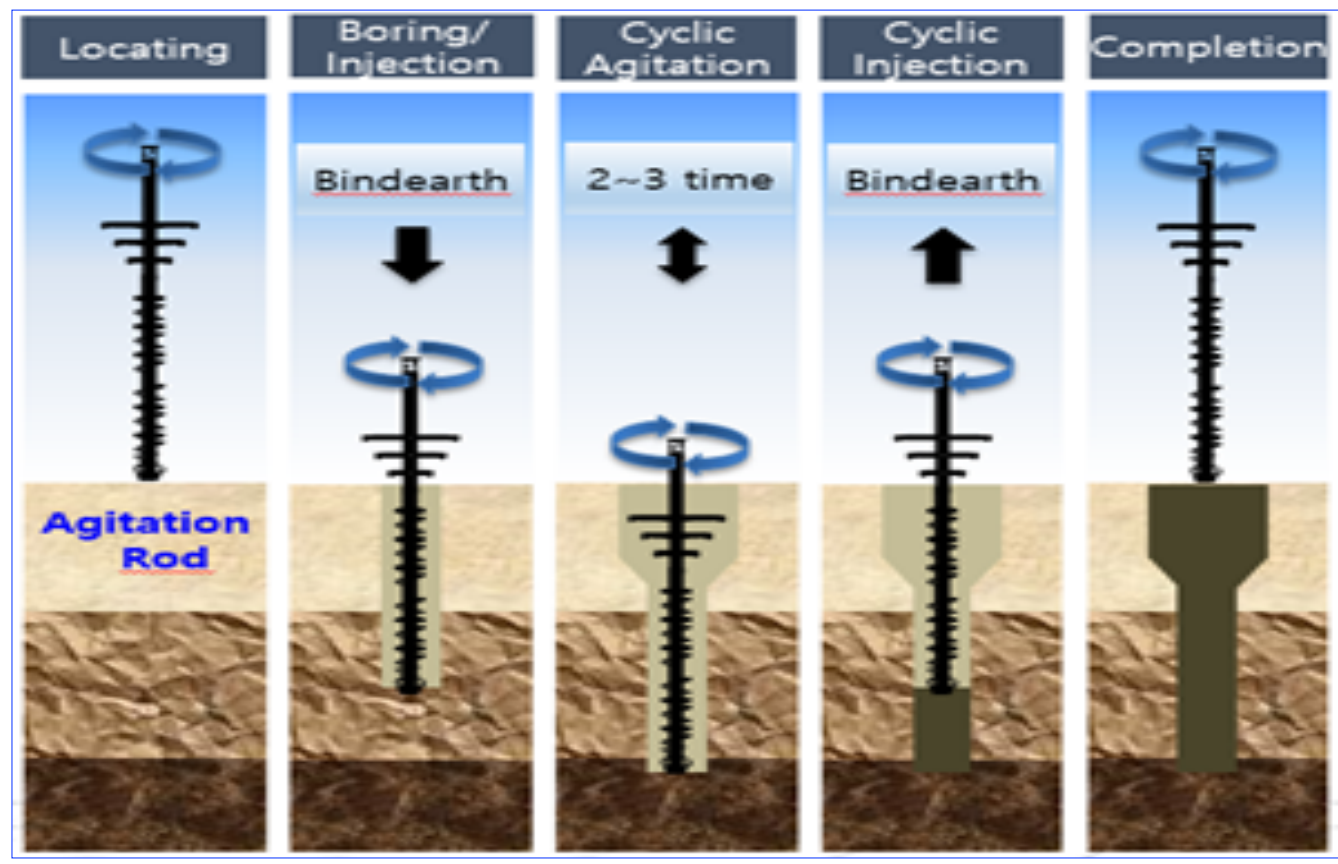

Fig. 8. Typical mixing steps for PF column (Nguyen et al., 2020)

\section{RESULTS AND DISCUSSIONS}

\section{The Soil Bearing Capacity}

As shown in Table 3, it can be seen that F-1400 is the largest foundation. Thus, in this study, the F-1400 foundation is used for calculation of capacity of the ground and the settlement of footings. The ultimate bearing capacity for square foundations after treated soft soil by PF method was calculated by Terzaghi's theory, Meyerhof 's theory, and Hansen's theory which was calculated from equation 6 to equation 8 . To assess the effectiveness of treatment soft soil by PF method, the ultimate bearing capacity of soft soil was also calculated. All results are shown in Table 4.

Table 4. Bearing capacity for the square foundations

\begin{tabular}{|c|c|c|c|c|}
\hline \multirow[b]{2}{*}{ No } & \multicolumn{3}{|c|}{ Bearing capacity for $400 \mathrm{KN}$ of square foundation of $2.5 * 2.5 \mathrm{~m}$} & \multirow[b]{2}{*}{$\begin{array}{c}\text { The demand } \\
\text { load, } Q_{\mathrm{a}} \\
\mathrm{kN} / \mathbf{m}^{2}\end{array}$} \\
\hline & $\begin{array}{c}\text { Terzaghi's bearing } \\
\text { capacity method, } \mathrm{kN} / \mathrm{m}^{2}\end{array}$ & $\begin{array}{c}\text { Meyerhof's bearing } \\
\text { capacity method, } \\
\text { kN/m² }\end{array}$ & $\begin{array}{c}\text { Hansen's bearing } \\
\text { capacity method, } \\
\mathbf{k N} / \mathbf{m}^{2} \\
\end{array}$ & \\
\hline Soft soil & 43.6 & 37.3 & 36.7 & 224 \\
\hline Treated soil by PF & 340.1 & 332.2 & 325.0 & 250 \\
\hline
\end{tabular}

As shown in Table 4, the results show that the soft soil is unstable and the bearing capacity is very smaller than the demand load. Otherwise, the square foundations after treated by PF method is stable and the ultimate bearing capacity of this foundation obtained from different calculation methods is about 8-9 times higher than that of native soil. 
In general, the difference in bearing capacity of the square foundation obtained from different methods is insignificant. The bearing capacity of soft ground before and after treatment by PF column was calculated by Terzaghi method is highest and was calculated by Hansen's method is smallest.

\section{The Settlement of Shallow Footing}

To calculate the settlement of ground, the profile of ground, and the detail of PF column were provided in Fig.9.

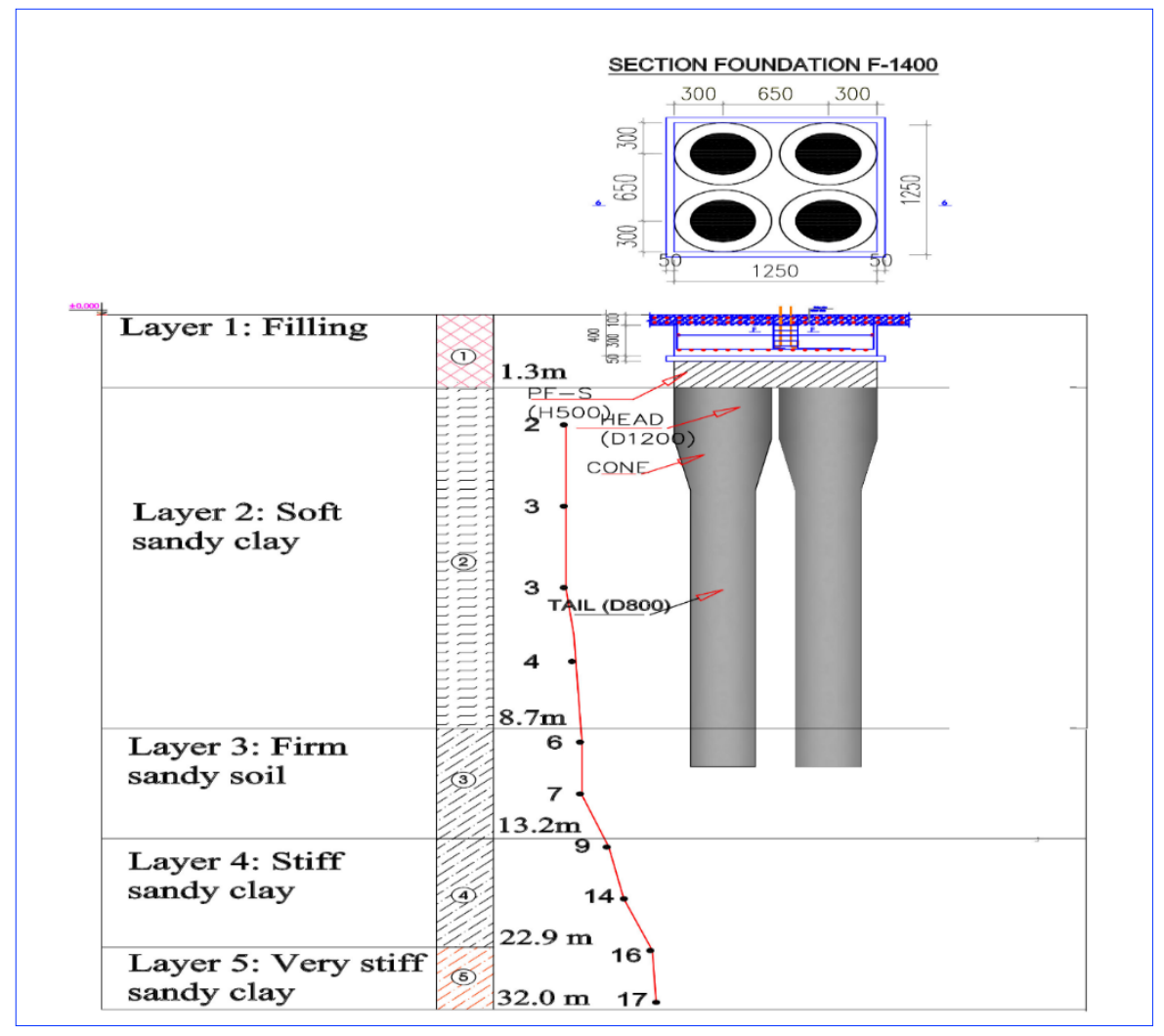

Fig. 9. Ground profile with PF columns

The settlement of shallow footings in natural soil (S0) and soil - PF column (S1) were calculated by equation 13 and equation 10 respectively (Table 5). Since layer 4 is in stiff state and layer 5 is in very stiff, the settlement of shallow footing in these layers is very small and the $h_{2}$ in equation 14 is only calculated for the firm layer. So, under the PE column, the settlement of natural soil under PF column $\left(\mathrm{S}_{2}\right)$ was determined by equation 14 and equals $0.25 \mathrm{~cm}$. The total settlement of shallow footings after improvement by PF column (S), which was calculated based on equation 9 is $2.43 \mathrm{~cm}$ and is smaller than the allowable settlement of $2.54 \mathrm{~cm}$ (EXT, 2017) or 8cm (Vietnamese Standard-TCVN 9362-2012, 2012). As compared to the settlement of soft soil, it is much smaller than the footing foundation on the native ground (the total of the settlement of foundation before improvement $\left(\mathrm{S}_{1}\right)$ is $\left.34.89 \mathrm{~cm}\right)$. 
Table 5. The settlement of shallow footings in natural soil $\left(S_{0}\right)$ and soil - PF column $\left(S_{1}\right)$

\begin{tabular}{|c|c|c|c|c|c|c|c|c|c|c|c|c|c|}
\hline Layer & PF & $\begin{array}{c}Z \\
\text { (m) }\end{array}$ & $\begin{array}{c}\mathrm{D} \\
\text { (m) }\end{array}$ & $\begin{array}{c}\mathbf{h}_{\mathbf{i}} \\
(\mathbf{m})\end{array}$ & $\begin{array}{c}\text { Ec-PF, } \\
(\mathrm{kPa})\end{array}$ & $\begin{array}{c}\text { Es soil, } \\
(\mathrm{kPa})\end{array}$ & $\begin{array}{c} \\
(\%)\end{array}$ & $\begin{array}{c}\mathbf{E}_{\mathrm{tb}}, \\
(\mathrm{kPa})\end{array}$ & $\begin{array}{c}S_{1} \\
(\mathrm{~cm})\end{array}$ & K0 & $\begin{array}{c}\sigma_{\mathrm{vo}}^{\prime} \\
\left(\mathbf{k N} / \mathbf{m}^{2}\right)\end{array}$ & $\begin{array}{c}\sigma_{\mathrm{pt}} \\
\left(\mathrm{kN} / \mathbf{m}^{2}\right)\end{array}$ & $\begin{array}{c}\mathrm{S}_{0}{ }^{1} \\
(\mathrm{~cm})\end{array}$ \\
\hline 2 & head & 2.3 & 1.2 & 1 & 300000 & 1500 & 72 & 217566 & 0.11 & 0.742 & 40.3 & 185.5 & 9.34 \\
\hline 2 & cone & 3.3 & 1.0 & 1 & 300000 & 1500 & 50 & 151466 & 0.16 & 0.559 & 41.3 & 139.7 & 7.04 \\
\hline 2 & tail & 4.3 & 0.8 & 1 & 300000 & 1500 & 32 & 97593 & 0.24 & 0.415 & 42.3 & 103.8 & 5.23 \\
\hline 2 & tail & 5.3 & 0.8 & 1 & 300000 & 1500 & 32 & 97593 & 0.24 & 0.312 & 43.3 & 78.1 & 3.93 \\
\hline 2 & tail & 6.3 & 0.8 & 1 & 300000 & 1500 & 32 & 97593 & 0.24 & 0.240 & 44.3 & 60.1 & 3.02 \\
\hline 2 & tail & 7.3 & 0.8 & 1 & 300000 & 1500 & 32 & 97593 & 0.24 & 0.189 & 45.3 & 47.2 & 2.38 \\
\hline 2 & tail & 8.3 & 0.8 & 1 & 300000 & 1500 & 32 & 97593 & 0.24 & 0.151 & 46.3 & 37.8 & 1.90 \\
\hline 2 & tail & 8.7 & 0.8 & 0.4 & 300000 & 1500 & 32 & 97593 & 0.10 & 0.139 & 46.7 & 34.8 & 0.70 \\
\hline 3 & tail & 9.3 & 0.8 & 0.6 & 300000 & 6500 & 32 & 100984 & 0.14 & 0.123 & 47.3 & 30.9 & 0.22 \\
\hline 3 & tail & 10.3 & 0.8 & 1 & 300000 & 6500 & 32 & 100984 & 0.23 & 0.085 & 48.3 & 21.3 & 0.25 \\
\hline 3 & tail & 11.3 & 0.8 & 1 & 300000 & 6500 & 32 & 100984 & 0.23 & 0.068 & 49.3 & 16.9 & 0.20 \\
\hline 3 & - & 13.2 & - & 1.9 & - & 6390 & - & - & - & 0.064 & 51.2 & 16.10 & 0.36 \\
\hline 4 & - & 14.2 & - & 1 & - & 13900 & - & - & - & 0.056 & 52.2 & 14.15 & 0.08 \\
\hline 4 & - & 15.2 & - & 1 & - & 13900 & - & - & - & 0.049 & 53.2 & 12.45 & 0.07 \\
\hline 4 & - & 16.2 & - & 1 & - & 13900 & - & - & - & 0.044 & 54.2 & 11,00 & 0.06 \\
\hline 4 & - & 17.2 & - & 1 & - & 13900 & - & - & & 0.039 & 55.2 & 9.80 & 0.05 \\
\hline \multicolumn{9}{|c|}{ Total settlement, $\mathrm{cm}$} & 2.18 & & & & 34.89 \\
\hline
\end{tabular}

\section{The Quality of Soil Treated by The PF Method}

To check the quality of improvement method, the PF column was excavated and measured the length and the width of PF column (Fig.10). After that, the sample P-E column was collected by the coring method. The samples were collected from the coring PF column and determined the unconfined compression strength. The coring samples were tested to determine the unconfined compression strength according to ASTM D2216 (2010).



Fig. 10. Checking the PF column after construction

As shown in Fig.11, the unconfined compression strength of coring samples ranged from $4000 \mathrm{kPa}$ to $4500 \mathrm{kPa}$, and the elastic modulus of the PF column varied from $350000 \mathrm{kPa}$ to 
$400000 \mathrm{kPa}$. It can be seen that the unconfined compressive strength and the elastic modulus of PF column are very high. As compared to the unconfined compressive strength of soil - DB 6000 for designing the method, the results showed that the unconfined compressive strength of the coring PF column is higher than the design of the unconfined compression strength. After the construction of PF-S, the static plate load test was performed (Fig.12). The results of this test are shown in Table 6.

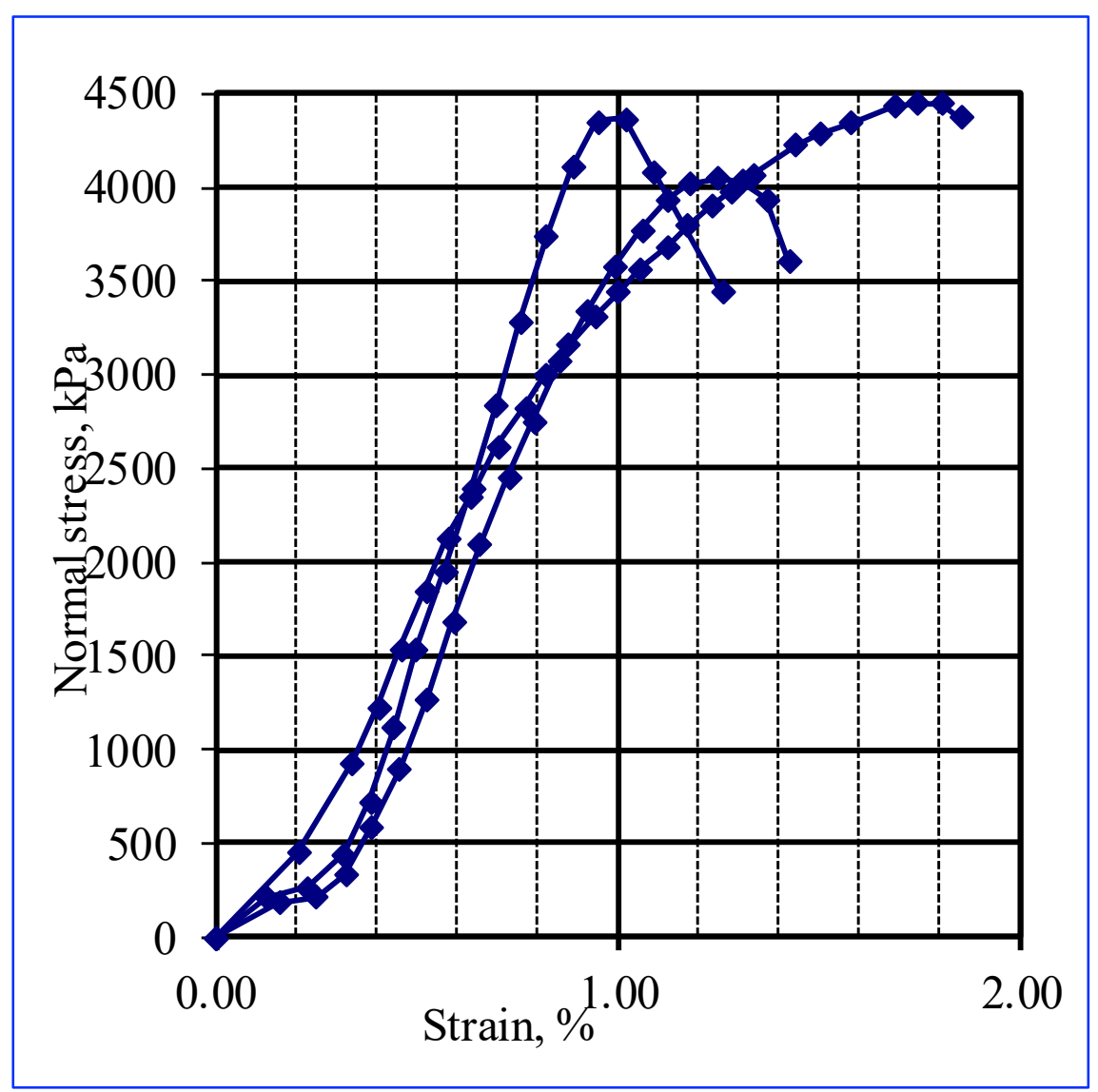

Fig. 11. The relationship of stress and strain of soil, DB 6000 mixing

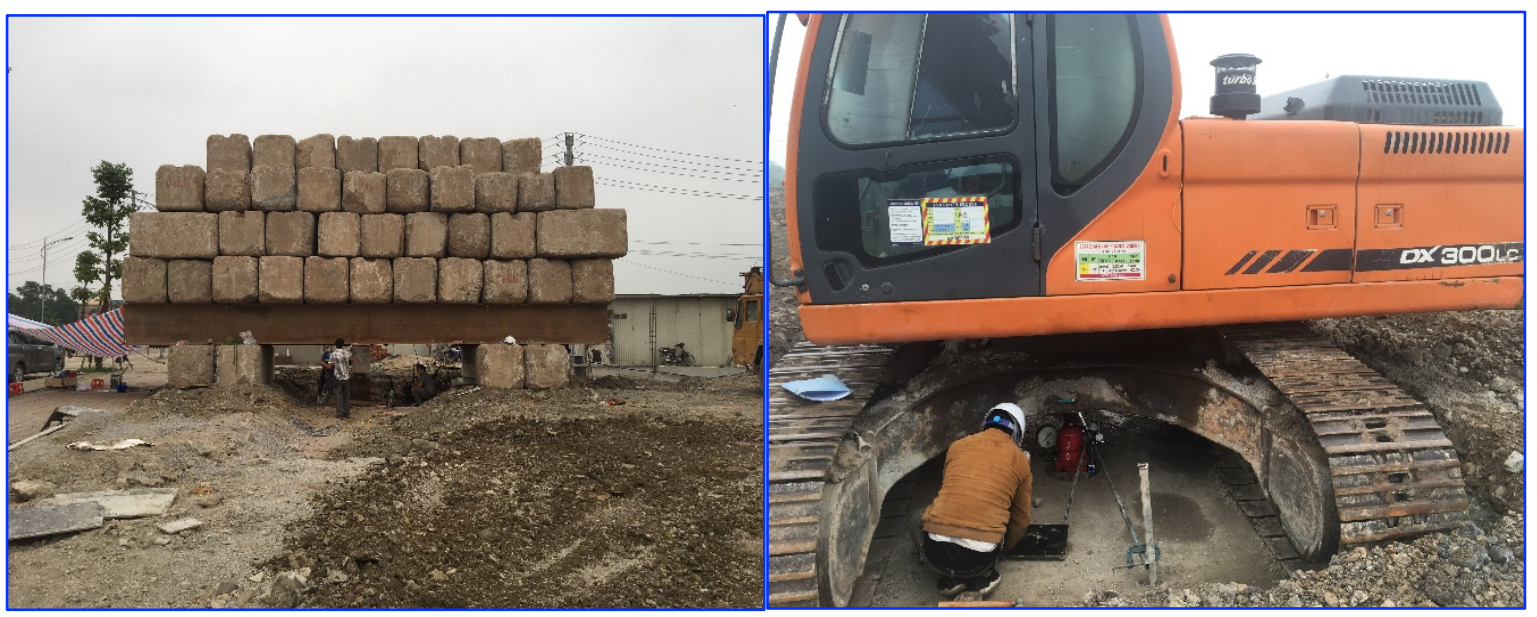

Fig. 12. The static plate load test for PF column 
Table 6. The static plate load test

\begin{tabular}{|c|c|c|c|c|c|c|}
\hline No & Cycle & $\begin{array}{c}\text { Load } \\
\%\end{array}$ & $\begin{array}{c}\text { Load } \\
\mathrm{kN} / \mathrm{m}^{2}\end{array}$ & $\begin{array}{c}\text { Time } \\
\text { minutes }\end{array}$ & $\begin{array}{c}\text { Settlement } \\
\text { mm }\end{array}$ & $\begin{array}{l}\text { Allowable settlement } \\
\qquad \mathrm{S}, \mathrm{mm}\end{array}$ \\
\hline 1 & \multirow{7}{*}{1} & 0 & 0 & 0 & 0.00 & 25.4 \\
\hline 2 & & 25 & 62.5 & 60 & 0.16 & 25.4 \\
\hline 3 & & 50 & 125 & 60 & 0.32 & 25.4 \\
\hline 4 & & 75 & 187.5 & 60 & 0.51 & 25.4 \\
\hline 5 & & 100 & 250 & 720 & 0.97 & 25.4 \\
\hline 6 & & 50 & 125 & 30 & 0.46 & 25.4 \\
\hline 7 & & 0 & 0 & 60 & 0.01 & 25.4 \\
\hline 1 & \multirow{10}{*}{2} & 50 & 125 & 30 & 0.33 & 25.4 \\
\hline 2 & & 100 & 250 & 30 & 0.79 & 25.4 \\
\hline 3 & & 125 & 312.5 & 60 & 1.13 & 25.4 \\
\hline 4 & & 150 & 375 & 60 & 1.50 & 25.4 \\
\hline 5 & & 175 & 437.5 & 60 & 1.88 & 25.4 \\
\hline 6 & & 200 & 500 & 720 & 2.61 & 25.4 \\
\hline 7 & & 150 & 375 & 30 & 2.38 & 25.4 \\
\hline 8 & & 100 & 250 & 30 & 1.92 & 25.4 \\
\hline 9 & & 50 & 125 & 30 & 1.22 & 25.4 \\
\hline 10 & & 0 & 0 & 60 & 0.39 & 25.4 \\
\hline
\end{tabular}

As shown in Table 6, the load in this test was increased and decreased in 2 cycles. At the first cycle, the load was increased to $0 \% ; 50 \% ; 75 \%$ and $100 \%$, then decreased to $50 \%$; $0 \%$ of demand load $\left(250 \mathrm{KN} / \mathrm{m}^{2}\right)$. At the second cycle, the load was increased to $0 \% ; 50 \% ; 100 \%$; $125 \% ; 150 \% ; 175 \%$ and $200 \%$, then decreased to $150 \% ; 100 \% ; 50 \%$ and $0 \%$ of demand load $\left(250 \mathrm{KN} / \mathrm{m}^{2}\right)$. After the test, although the maximum load was 1-2 times higher than the demand load, PF column was not destroyed. The settlement of PF column at the maximum load of the first cycle is $0.95 \mathrm{~mm}$ and is much smaller than the allowable settlement $(25.4 \mathrm{~mm})$. At the maximum load of the second cycle, the settlement of PF column is $2.61 \mathrm{~mm}$ and is larger than that of the first cycle, but is also smaller than allowable settlement $(25.4 \mathrm{~mm})$. The results also showed that the increase in load increased the settlement. In general, the capacity and settlement of the PF column can be satisfied with the requirement of construction building.

\section{CONCLUSIONS}

This paper represents the case study of applying the PF method for treating soft soil for building the foundation of Samse Vina factory, Ninh Binh province. From the research results, some conclusions can be drawn as follows: 
The soft soil is widely distributed in the area of Samse Vina factory with the thickness varying from a few meters to more than 10 meters. The soft soil layer distributes at a shallow depth; has a low bearing capacity and cannot meet the construction load. The PF method can significantly increase the bearing capacity and reduce the settlement of soil ground. According, the bearing capacity of treated ground using PF is about 8-9 times that of the native ground while the settlement of the treated ground is also much lower than that of the native ground. The PF method can be used for the foundation with a load of less than 250 tons. The use of DB6000 with high compressive strength can reduce the content of adhesives. Thus, the use of PF method can save time, cost and it is friendly with the environment. The load capacity of ground improved by the PF column can be satisfied with the construction requirement. The unconfined compressive strength and elastic modulus of treated soil are high.

\section{ACKNOWLEDGMENTS}

We would like to thank the support of Ha Noi University of Mining and Geology, Ministry of Education and Training to complete this study. We are very grateful to the reviewers for their appropriate and thoughtful suggestions to improve the paper. The authors are very grateful to the Editor in Chief Prof. Dr. Salih M. Awadh, the Secretary of Journal Mr. Samir R. Hijab and the Technical Editor Dr. Heba S. Al-Mimar for their great efforts and valuable comments.

\section{REFERENCES}

Al-Hamdani, J. A. J, Awadh, S. M., and Ibrahim, O. S., 2016. Geochemical partitioning of heavy metals in Urban soil, Kirkuk, Iraq. Iraqi Geological Journal., 39-49.

An, P.V., 2012. Discussion calculation method of CDM. Journal of science and technology. 11: 17-20.

ASTM D422-63, 2007. Standard Test Method for Particle-Size Analysis of Soils.

ASTM D2216, 2010. Standard Test Methods for Laboratory Determination of Water (Moisture) Content of Soil and Rock by Mass.

ASTM D2485-18, 2018. Standard Test Methods for Evaluating Coatings For High Temperature Service.

ASTM D3080-04, 2004. Standard Test Method for Direct Shear Test of Soils Under Consolidated Drained Conditions.

ASTM D4318-17, 2017. Standard Test Methods for Liquid Limit, Plastic Limit, and Plasticity Index of Soils.

Asturias, R. P., Lorenzo, G. A., 2015. Unconfined compression behavior of cement treated non-plastic soil reinforced with small diameter steel bars. International Journal of Engineering Technology. 15: 29-34.

Bowles, L. E., 1996. Foundation analysis and design. McGraw-hill.

Bruce, D. A., 2000. An introduction to the deep soil mixing methods as used in geotechnical applications. Publication No. FHWA-RD-99-138, 135 P.

Bui Truong, S., Nguyen Thi, N., and Nguyen Thanh, D., 2020. An Experimental study on unconfined compressive strength of soft soil-cement mixtures with or without GGBFS in the coastal area of Vietnam. Advances in Civil Engineering.

Chen, J.J., Zhang, L., Zhang, J.F., Zhu, Y.-F., and Wang, J.H., 2013. Field tests, modification, and application of deep soil mixing method in soft clay. Journal of Geotechnical and Geoenvironmental Engineering. 139: 24-34.

Dehghanbanadaki, A., Ahmad, K., Ali, N., Khari, M., Alimohammadi, P. and Latifi, N., 2013. Stabilization of soft soils with deep mixed soil columns, general perspective. Electronic Journal of Geotechnical Engineering. 18: 295-306. 
EXT, 2017. Point Foundation, a foundation method for weak soil reinforcement using environmentally-friendly, highly functional binders.

Giao, P. H. and Hien, D. H., 2007. Geotechnical characterization of soft clay along a highway in the Red River Delta. Journal of Lowland Technology International 9:18-27.

Nguyen, A. N., Nguyen, T. D., Yim, C. S., and Lee, M. S., 2020. Point foundation (PF) method for foundations and embankments, in: Geotechnics for Sustainable Infrastructure Development. Springer, 571-578.

Nguyen, T. D., Hoang, D. P., Tran, Q. G., and Chung, S. G., 2020. Aanalytical and Numerical Analyses on Stiffness Enhancement of Ground Improved by Head-Enlarged CDM Columns, in: Geotechnics for Sustainable Infrastructure Development. Springer, 579-586.

Nguyen Thi, N., Phi Hong, T., and Bui Truong, S., 2019. Utilizing coal bottom ash from thermal power plants in Vietnam as partial replacement of aggregates in concrete pavement. Journal of Engineering.

Nguyen Thi, N., Bui Truong, S. and Do Minh, N., 2020. Research on horizontal coefficient of consolidation of Vietnam's soft soil. Journal of Engineering 2020.

Nu, N. T., Phi, H. T. and Son, B.T., 2020. Determination of particles and minerals content in soft clay soil of the Mekong Delta Coastal Provinces, Southern Vietnam for inorganic adhesives stabilization. Iraqi Journal of Science, 791-804.

Nu, N. T, Duong, N. T, Son, B. T and Thinh, P. H., 2020. Investigation of salt, alum content in soft soils and their effects on soil properties: Case study in coastal areas of Vietnam. Iraqi geological Journal, 53 (2A):1934.

Nu, N. T. and Son, B.T., Ngoc, D. M., 2019. An experimental study of reusing coal ash for base course of road pavement in Vietnam. Electronic Journal of Geotechnical Engineering. 24: 945-960.

Nu, N.T. and Thinh, P. H., 2020. Soft soils in the Mekong delta of Vietnam. ActuAlscience 10.

Vietnamese Standard-TCVN 9362-2012, 2012. Specification for design of foundation for buidings and structures.

Vietnamese Standard-TCVN 9403-2012, 2012. Stabilization of soft soil -- the soil cement colum method. 